\title{
The physico-chemical habitat template for periphyton in alpine glacial streams under a changing climate
}

\author{
Journal Article \\ Author(s): \\ Uehlinger, Urs; Robinson, Christopher T.; Hieber, Mäggi; Zah, Rainer \\ Publication date: \\ 2010-12 \\ Permanent link: \\ https://doi.org/10.3929/ethz-b-000023355 \\ Rights / license: \\ In Copyright - Non-Commercial Use Permitted \\ Originally published in: \\ Hydrobiologia 657(1), https://doi.org/10.1007/s10750-009-9963-x
}




\title{
The physico-chemical habitat template for periphyton in alpine glacial streams under a changing climate
}

\author{
U. Uehlinger · C. T. Robinson · M. Hieber • \\ R. Zah
}

Received: 10 May 2009/Accepted: 5 October 2009/Published online: 20 November 2009

(C) Springer Science+Business Media B.V. 2009

\begin{abstract}
The physico-chemical habitat template of glacial streams in the Alps is characterized by distinct and predictable changes between harsh and relatively benign periods. Spring and autumn were thought to be windows of favorable environmental conditions conducive for periphyton development. Periphyton biomass (measured as chlorophyll $a$ and ash-free dry mass) was quantified in five glacial and three nonglacial streams over an annual cycle. One glacial stream was an outlet stream of a proglacial lake. In all glacial streams, seasonal patterns in periphyton were
\end{abstract}

Guest editors: R. J. Stevenson, S. Sabater / Global Change and River Ecosystems-Implications for Structure, Function and Ecosystem Services

U. Uehlinger $(\bowtie) \cdot$ C. T. Robinson

Department of Aquatic Ecology, Swiss Federal Institute of Aquatic Science and Technology (Eawag),

8600 Dübendorf, Switzerland

e-mail: uehlinger@eawag.ch

U. Uehlinger $\cdot$ C. T. Robinson

Institute of Integrative Biology, ETH Zürich, Zürich,

Switzerland

M. Hieber

INTERTEAM, Untergeissenstein 10/12, 6005 Luzern,

Switzerland

\section{R. Zah}

Department Sustainable Information Technology, Swiss Federal Institute for Material Testing (EMPA),

Lerchenfeldstrasse 5, 9014 St. Gallen, Switzerland characterized by low biomass during summer high flow when high turbidity and transport of coarse sediment prevailed. With the end of icemelt in autumn, environmental conditions became more favorable and periphyton biomass increased. Biomass peaked between late September and January. In spring, low flow, low turbidity, and a lack of coarse sediment transport were not paralleled by an increase in periphyton biomass. In the non-glacial streams, seasonal periphyton patterns were similar to those of glacial streams, but biomass was significantly higher. Glacier recession from climate change may shift water sources in glacier streams and attenuate the glacial flow pulse. These changes could alter predicted periods of optimal periphyton development. The window of opportunity for periphyton accrual will shift earlier and extend into autumn in channels that retain surface flows.

Keywords Alpine - Algae - Primary production . Stream · Flow regime $\cdot$ Glacier $\cdot$ Ecological windows

\section{Introduction}

Glacial streams are common landscape features of high latitudes and mountain ranges ascending above the permanent snow line. Glacial streams are yearround cold habitats with a characteristic fauna (Ward, 1994; Füreder, 1999), and in temperate latitudes, the only remnants for cold-adapted lotic organisms since 
the end of the last ice age. However, these habitats are under severe threat as ongoing global warming has dramatically accelerated glacier recession. For instance, glaciers in Switzerland lost $\sim 20 \%$ of their area from 1985 to 1998 (Paul, 2003) and 80 to $>90 \%$ of the Alpine glacier mass may be lost by 2100 (Watson et al., 1997; Zemp et al., 2006). The consequences of such a scenario would be the widespread loss of Alpine glacial streams, with most streams then being fed by snowmelt or groundwater (Milner et al., 2009).

The ecology of alpine streams, glacial streams in particular, has attracted much interest driven by scientific curiosity and concerns about the impact of climate change (e.g., Milner \& Petts, 1994; Ward \& Uehlinger, 2003; Milner et al., 2009). However, most studies have focused on benthic invertebrates and largely ignored the energy base of these systems (e.g., Burgherr, 2000; Castella et al., 2001; Robinson et al., 2001; Brown et al., 2006). Primary production in wetted channels and allochthonous inputs of organic matter from adjacent riparian zones provide the basal energy supporting heterotrophic communities in lotic ecosystems. High latitude streams and alpine headwaters drain catchments with sparse or even absent vegetation, and consequently, inputs of particulate organic matter from the riparian zone into stream channels are low or lacking (McKnight \& Tate, 1997; Zah \& Uehlinger, 2001). Some studies suggest that benthic algae are the dominant energy source in these streams (Lavandier \& Décamps, 1984, McKnight \& Tate, 1997; Uehlinger \& Zah, 2003), and only a few investigations exist on the structure of benthic algal communities of high altitude alpine streams (see review by Rott et al., 2006). For instance, benthic algae in glacial streams of Antarctica have been examined by various investigators (Howard-Williams et al., 1986; Howard-Williams \& Vincent, 1989; Vincent \& Howard-Williams, 1989; Hawes et al., 1992), but seasonal patterns are presumably unlike those of glacial streams in temperate latitudes because of differences in flow regime, including periods of scouring flow, and photoperiod.

In glacial streams of the Alps, the radiation and temperature controlled release of water between early summer and autumn occurs in the form of a distinct and predictable flow pulse (Tockner et al., 2000; Uehlinger et al., 2003) during which bed load transport, high concentration of suspended solids (high turbidity), and relatively low temperatures prevail (Milner \& Petts, 1994). In winter, stream channels can be covered by snow, freeze or fall dry (Malard et al., 2006). In contrast to the harsh environment in summer and winter, more benign conditions prevail during spring and autumn when flow is relatively low (no bed load transport), temperature moderate, and light conditions little affected by suspended solids. Therefore, it has been hypothesized that spring and autumn are ecological windows of opportunity for benthic algae, i.e., periods favoring the accrual of algal biomass otherwise constrained by factors such as moving bed sediments and limited light availability (Uehlinger et al., 2002; Milner et al., 2009). In a year-long study of a glacial river, periphyton dynamics reflected to some extent this seasonal change between harsh and benign habitat conditions (Uehlinger et al., 1998).

The objectives of this study were to (1) examine seasonal periphyton development in glacial streams over an annual cycle with regard to the environmental features that characterize the physico-chemical habitat template of Alpine glacial streams; i.e., to what extent annual patterns in periphyton biomass correspond to the above mentioned concept of ecological windows (Uehlinger et al., 2002) and (2) discuss how ongoing climate change may affect the physicochemical habitat template and, as a consequence, periphyton, which is assumed to be the autotrophic energy base of these streams. This study was part of a comprehensive investigation of high altitude Alpine streams that focused on benthic invertebrates and benthic algae (Hieber et al., 2001, 2002, 2005; Robinson et al., 2001; Zbinden et al., 2008). In order to better evaluate the glacial influence, we used data from three non-glacial streams that were at similar elevations and with year-round data available.

\section{Methods}

Study sites

The glacial streams studied were located downstream of the termini of five rapidly receding valley glaciers in the Swiss Alps (inset Fig. 1). Site elevations varied from 1,210 to $2,159 \mathrm{~m}$ a.s.l., and catchment areas from 14 to $35 \mathrm{~km}^{2}$ (Table 1). Between 40 and $70 \%$ of individual catchments were covered by glaciers. 


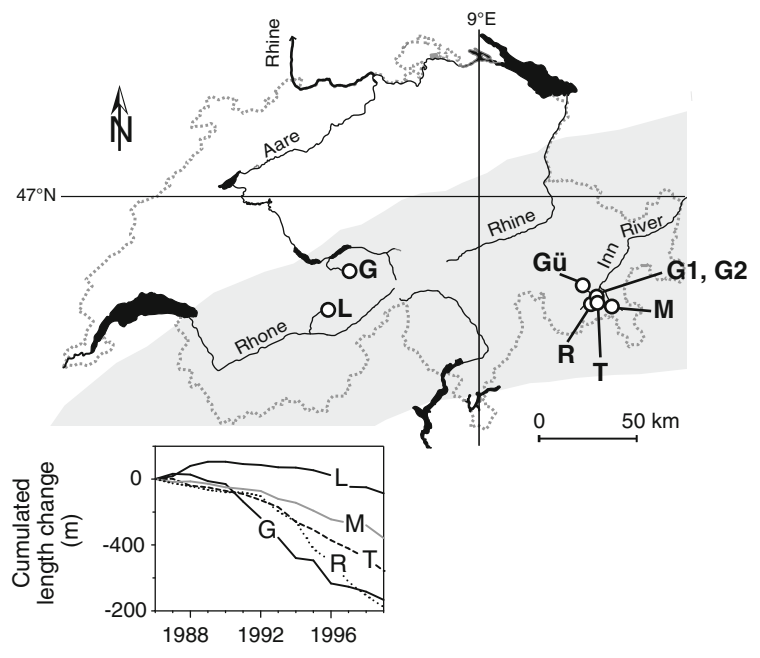

Fig. 1 Map of the study sites (open circles) within the Swiss Alps (shaded area). Major lakes are black. L Lang Glacier, $G$ Oberer Grindelwald Glacier, $R$ Lake outlet of the proglacial Roseg Lake, $T$ Tschierva Glacier, $M$ Morteratsch Glacier. $G 1$ and $G 2$ Groundwater-fed streams in the Val Roseg. Gü Güglia. The inset shows the cumulated length change of the five glaciers since 1987 (data provided by the World Glacier Monitoring Service, Zurich)

Morphological data and catchment characteristics are given in Table 1. One stream (Roseg) is the outlet of a proglacial lake; i.e., the Roseg Glacier ends in a 1.2$\mathrm{km}$ long proglacial lake (area $0.22 \mathrm{~km}^{2}$ ) confined by the lateral moraine of the adjacent Tschierva Glacier. Melt waters of both glaciers merge in the foreland of the Tschierva Glacier to form the Roseg River. In four of the five catchments, the underlying bedrock was granite or granitoids. Sedimentary rock (limestone) only occurred in the lowest part of the upper Grindelwald Glacier drainage. In glacial streams, sampling took place from July 1998 to September/ October 1999. Study sites were visited at about monthly intervals from spring to autumn. During winter, sampling was less frequent because snow restricted site access. The sites below the Lang Glacier could not be sampled from December to April. The non-glacial streams comprised two perennial groundwater-fed streams (G1 and G2) located in the Val Roseg flood plain, at about 2,030 $\mathrm{m}$ a.s.l., and the Güglia, an alpine stream fed by snowmelt and groundwater, at 2,205 $\mathrm{m}$ a.s.1. The groundwater-fed streams were sampled from July 1996 to January 1999, and the Güglia was sampled from July 1999 to August 2000.
Physics and chemistry

Gauging stations of the Federal Office for Water and Geology recorded discharge 8-15 km downstream of each glacier stream. At these stations, the recorded discharge also included water from glacial tributaries joining the study river between the lowermost sampling sites and the gauging station. In order to estimate discharge for the study reaches, we allocated the discharge to study rivers and tributaries proportional to the glacier surface. For the Tschierva and Roseg glacier streams, discharge recorded at the gauging station in Pontresina was allocated to each stream using temperature as a tracer (Uehlinger et al., 2003). Continuous discharge records of non-glacial streams were not available. Discharge of these streams was measured a few times using the tracer dilution method (Gordon et al., 1992) or the velocity area method (Davis et al., 2001).

As an indicator of bed sediment stability, we estimated the critical discharge for initiation of bed sediment transport based on channel geometry, average slope, and grain size distribution according to Günter (1971) and Gessler (1965). In each stream, one temperature logger (StowAway, Onset Computer Corp., Pocasset MS, USA or Minilog, Vemco Ltd., Shad Bay N.S., Canada) was installed between the upper and lower sites. Loggers were enclosed in stainless steel housings and fixed with a chain to a metal rod on the bank.

Snow cover at the study sites was estimated each time when the sites were visited, but more comprehensive snow data are lacking. Information on light availability at the channel bottom at the study sites was not available.

Specific conductance $\left(\mu \mathrm{S} \mathrm{cm} \mathrm{cm}^{-1}\right.$ at $\left.20^{\circ} \mathrm{C}\right)$ was measured with a conductivity meter (LF323, WTW, Weilheim, Germany). Turbidity (nephelometric turbidity units: NTU) was determined using a portable turbidity meter (Cosmos, Züllig, Rheineck, Switzerland). Surface water (1 l) was collected from each stream on each sample date, returned to the laboratory in a cooler, and then filtered through pre-ashed glass fiber filters (GF/F, Whatman). The filtrate was analyzed for $\mathrm{NH}_{4}-\mathrm{N}, \mathrm{NO}_{3}-\mathrm{N}$, soluble reactive phosphorus (SRP), and particulate phosphorus (PP). Analytical methods are described in detail by Tockner et al. (1997). 


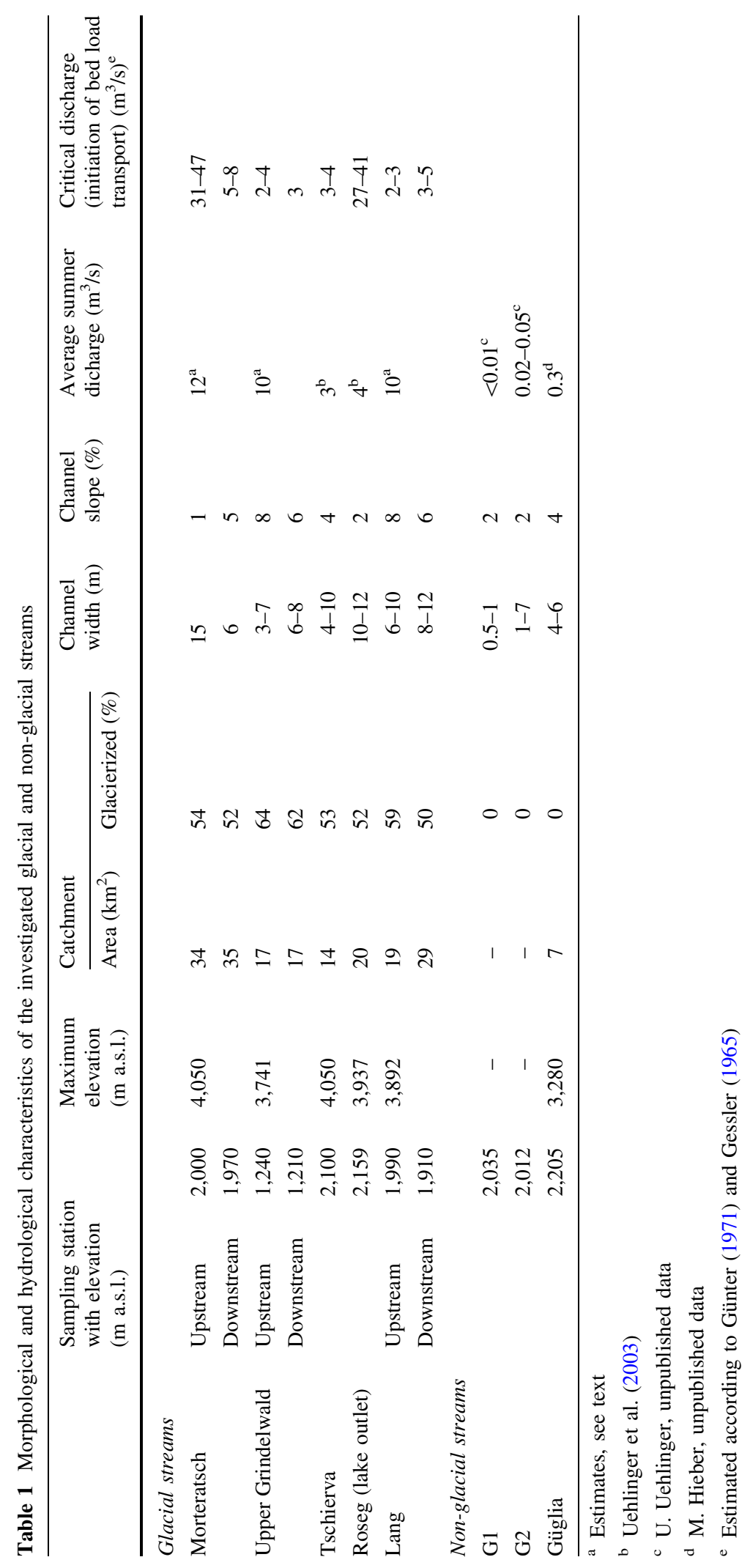


Periphyton

For determination of periphyton biomass, 10 rocks were randomly collected at each site along a 20-m long section of channel. Collected rocks were transported to the laboratory in a cooler. Algae were removed from each stone with a brass wire brush and rinsed into a bucket. Aliquots of the suspension were filtered through glass fiber filters (Whatman GF/F) for analysis of chlorophyll $a$ and ash-free dry mass (AFDM). The remaining suspensions were composited, and an aliquot of $20 \mathrm{ml}$ preserved in $2 \%$ formalin for later identification of algae (a detailed description has been given by Hieber et al., 2001). The filters for chlorophyll $a$ analysis were transferred to individual screw-cap vials filled with $6 \mathrm{ml}$ ethanol $(90 \% \mathrm{v} / \mathrm{v})$, boiled at $76^{\circ} \mathrm{C}$ for $10 \mathrm{~min}$, and stored in the dark at $4^{\circ} \mathrm{C}$ until analyzed. Chlorophyll $a$ was determined by HPLC (Meyns et al., 1994). For determination of AFDM, filters were dried at $60^{\circ} \mathrm{C}$, weighed, ashed for $3 \mathrm{~h}$ at $500^{\circ} \mathrm{C}$, and reweighed. Area values of chlorophyll $a\left(\mathrm{mg} / \mathrm{m}^{2}\right)$ and AFDM were calculated as described in Uehlinger (1991).

Data analysis

In order to evaluate the effect of stream type (glacial and non-glacial) and season, we used analysis of variance (ANOVA) followed by Tukey's multiple comparison test. Prior to analysis, data were transformed $\log (x+1)$ to improve normality (Zar, 1996). Effects were considered significant at $P<0.05$. We defined the length of each season as follows: (1) spring: April and May; (2) summer: June 1-September 15; (3) autumn: September 16-November 15; and (4) winter: November 16-March 31. These season lengths approximately correspond to the glacial hydrograph: snowmelt/flow increase from April to end of May, summer high flow/ice melt until the first half of September, subsequent autumnal flow decline, and the extended winter low flow (Fig. 2).

\section{Results}

The physico-chemical environment

The overall discharge pattern (vernal flow increase, summer high flow, autumnal flow recession, winter low flow) was similar in all glacial streams including the Roseg Lake outlet. Cold weather periods (reduced icemelt) and spates induced by rain storms resulted in substantial (stochastic) flow variation in summer and autumn (Fig. 2). The estimated critical flow for initiation of bed sediment transport was frequently exceeded during summer, except for the proglacial Roseg Lake outlet and the upper Morteratsch site. Both of these sites are characterized by wide channels and relatively small slopes (Table 1). Discharge in the groundwater-fed streams of the Val Roseg varied from 1996 to 1999 between 0.005 in autumn/winter and $0.06 \mathrm{~m}^{3} \mathrm{~s}^{-1}$ in late spring (snow melt) and between 0.24 and $0.37 \mathrm{~m}^{3} \mathrm{~s}^{-1}$ in the Güglia from 1999 to 2000 . Movement of bed sediments can be excluded in the groundwater-fed streams, but bed load transport cannot be excluded during snow melt in May/June and rainstorm induced spates in the Güglia.

Figure 3 illustrates seasonal patterns of daily mean temperatures in three glacial and two non-glacial streams. Daily mean water temperatures during summer varied between 0.5 and $2.1^{\circ} \mathrm{C}$ in the glacial streams below Morteratsch, upper Grindelwald, Lang, and

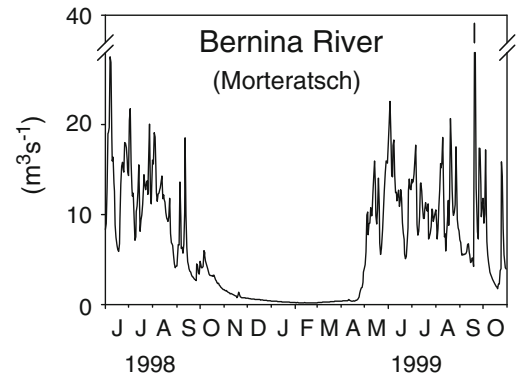

Fig. 2 Daily discharge downstream of four study sites from June 1998 to October 1999. Gauging stations were $5 \mathrm{~km}$ (Bernina River), $6 \mathrm{~km}$ (Lonza), and $10.5 \mathrm{~km}$ (Roseg)
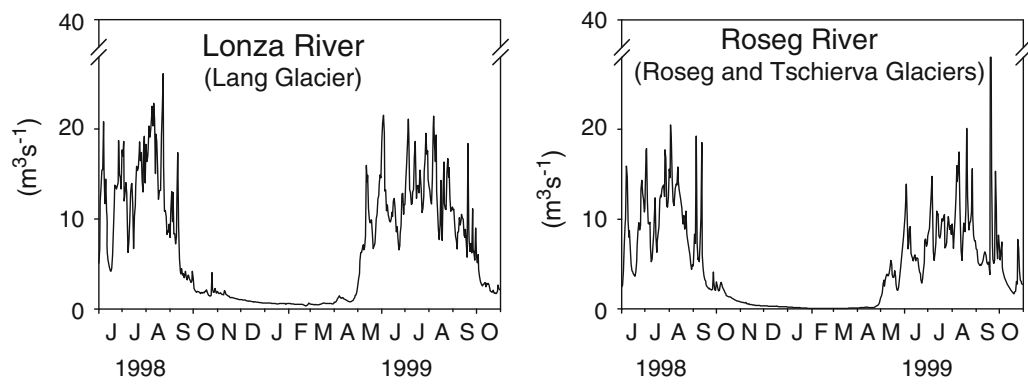

downstream of the study sites. At the Roseg River gauging station discharge included the meltwater of both Tschierva and Roseg Glaciers 
Fig. 3 Daily temperatures based on logger records in three glacial (A) and two non-glacial streams $(\mathbf{B})$
A

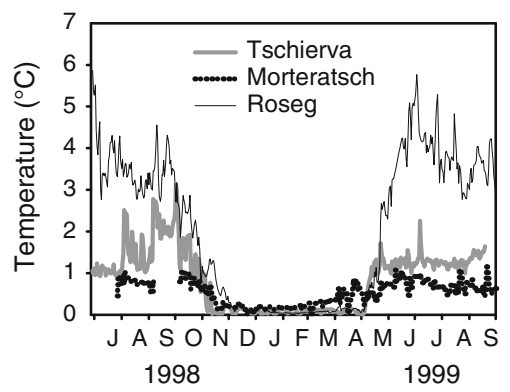

B

1999

2000

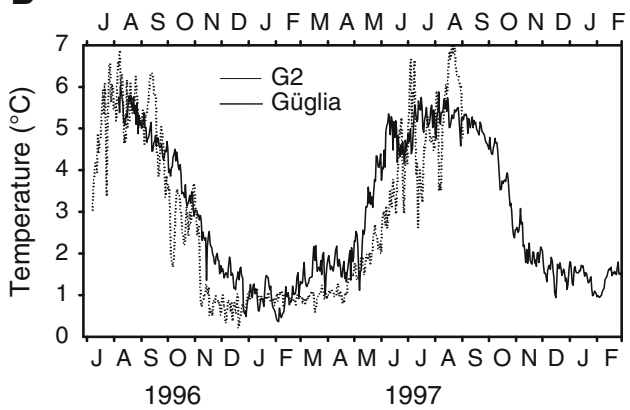

Tschierva Glacier, and between 2.6 and $7.0^{\circ} \mathrm{C}$ in the Roseg Lake outlet. Winter temperatures ranged from 0.0 to $1.6^{\circ} \mathrm{C}$ (glacial and non-glacial streams). Daily mean temperatures in the non-glacial streams ranged from 3.7 to $5.9^{\circ} \mathrm{C}$ in the Val Roseg floodplain and from 3.9 to $7.1^{\circ} \mathrm{C}$ in the Güglia during summer.

In glacial streams, turbidity was significantly higher (annual average $125 \pm 128$ NTU) than in non-glacial streams (annual average $1.9 \pm 3.4 \mathrm{NTU}$ ) and significantly varied with season (Fig. 4A). Turbidity was low from December to April ( $<5$ NTU) except from the Roseg Lake outlet, where it ranged from 30 to $55 \mathrm{NTU}$, began to increase by the end of April, peaked between June and mid-September, and was still relatively high in autumn. The investigated non-glacial streams exhibited no significant seasonal variation.
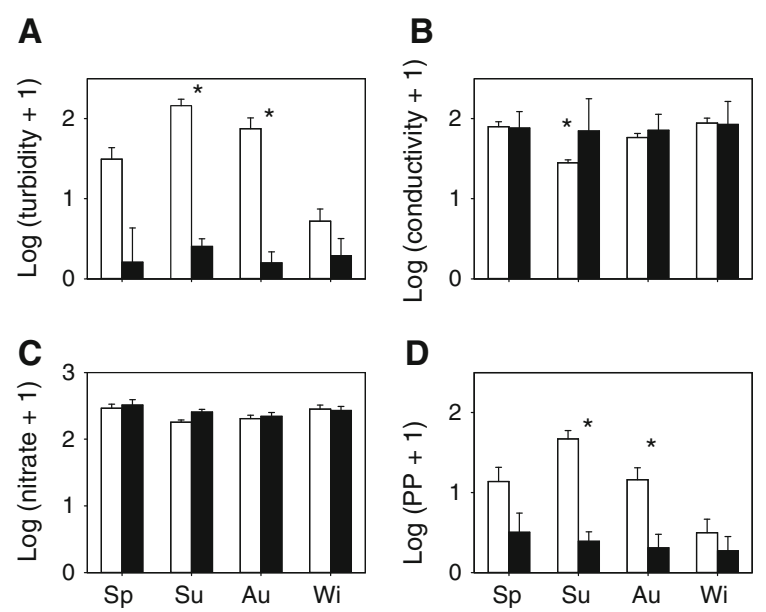

Fig. 4 Seasonal variability of turbidity (A), conductivity (B), nitrate $(\mathbf{C})$ and PP (D) in glacial and non-glacial streams. Bar plots with standard errors. Open bars = glacial streams. Filled bars = non-glacial streams. Asterisks indicate significant differences between the two stream types (post-hoc Tukey's test). $S p$ Spring, $S u$ summer, $A u$ Autumn, Wi winter
Snow covered the channel below the Tschierva Glacier from January to April 1999. The upper and lower sites below the Grindelwald Glacier were snow covered by 90 and $60 \%$, respectively, in January 1999, and by 100 and $90 \%$ until April after a heavy snowfall in February 1999. The Tschierva site was snow covered in January and February (presumably to mid of April). The Roseg Lake outlet site was open during winter as well as the upstream Morteratsch site. At the lower Morteratsch site, snow free areas were restricted to a few areas (about $1-2 \mathrm{~m}^{2}$ ) until a large snowfall in February deeply covered the stream until mid April 1999. The two groundwater-fed channels in the Roseg flood plain as well as the Güglia site were not snow covered during winter.

In glacial streams, conductivity reflected the seasonality in glacial influence (Fig. 4B). In nonglacial streams, conductivity was higher and lacked seasonal variation (Table 2). In both stream types, nitrate concentrations were relatively high with maximum concentrations during spring (Table 2; Fig. 4C). In glacial streams, ammonia concentrations were 2-8 fold higher than in non-glacial streams (Table 2); the difference mainly resulted from the significantly elevated concentrations during the summer ice melt. Concentrations of SRP were generally low (Table 2), often below the detection limit $(<1 \mu \mathrm{g}$ $\mathrm{P}^{-1}$ ), and showed no seasonal pattern in both stream types. PP was high in glacial streams and varied seasonally like turbidity (Table 2; Fig. 4D). The low $\mathrm{PP}$ concentrations in non-glacial streams lacked any seasonality.

\section{Periphyton}

Figure 5 depicts seasonal patterns of chlorophyll $a$ in the investigated streams (ash-free dry mass showed 
Table 2 Conductivity, inorganic nitrogen and phosphorus compounds (mean and standard deviation) of the five streams during the study period

\begin{tabular}{|c|c|c|c|c|c|}
\hline & Conductivity $\left(\mu \mathrm{S} \mathrm{cm}^{-1}\right)$ & $\mathrm{NH}_{4}-\mathrm{N}\left(\mu \mathrm{g} \mathrm{l}^{-1}\right)$ & $\mathrm{NO}_{3}-\mathrm{N}\left(\mu \mathrm{g} \mathrm{l}^{-1}\right)$ & $\operatorname{SRP}\left(\mu \mathrm{g}^{-1}\right)$ & $\mathrm{PP}\left(\mu \mathrm{g}^{-1}\right)$ \\
\hline \multicolumn{6}{|c|}{ Glacial streams } \\
\hline Grindelwald & $88 \pm 52$ & $14 \pm 12$ & $234 \pm 107$ & $1 \pm 1$ & $49 \pm 58$ \\
\hline Lang & $53 \pm 28$ & $20 \pm 12$ & $138 \pm 59$ & $1 \pm 1$ & $112 \pm 66$ \\
\hline Tschierva & $52 \pm 32$ & $8 \pm 9$ & $329 \pm 120$ & $3 \pm 1$ & $130 \pm 224$ \\
\hline Morteratsch & $47 \pm 33$ & $25 \pm 30$ & $263 \pm 65$ & $2 \pm 2$ & $69 \pm 127$ \\
\hline Roseg & $45 \pm 19$ & $21 \pm 21$ & $174 \pm 42$ & $2 \pm 1$ & $31 \pm 19$ \\
\hline \multicolumn{6}{|c|}{ Non-glacial streams } \\
\hline G1 & $98 \pm 26$ & $4 \pm 8$ & $365 \pm 114$ & $2 \pm 1$ & $3 \pm 3$ \\
\hline $\mathrm{G} 2$ & $64 \pm 20$ & $4 \pm 3$ & $266 \pm 95$ & $1 \pm 1$ & $2 \pm 2$ \\
\hline Güglia & $88 \pm 12$ & $3 \pm 4$ & $176 \pm 52$ & $<1 \pm<1$ & $1 \pm 1$ \\
\hline
\end{tabular}

$G 1$ and $G 2$ are groundwater-fed streams in the Roseg floodplain

Fig. 5 Chlorophyll $a$ time series in five glacial and three non-glacial streams located in the Alps
Glacial streams

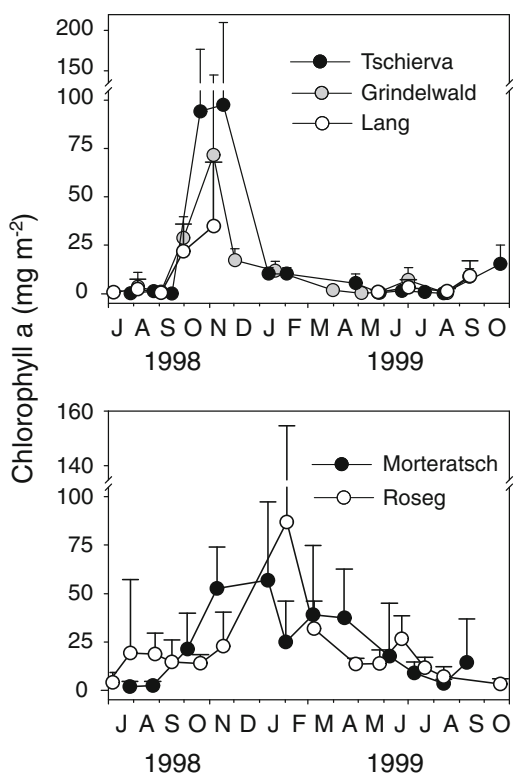

Non-glacial streams

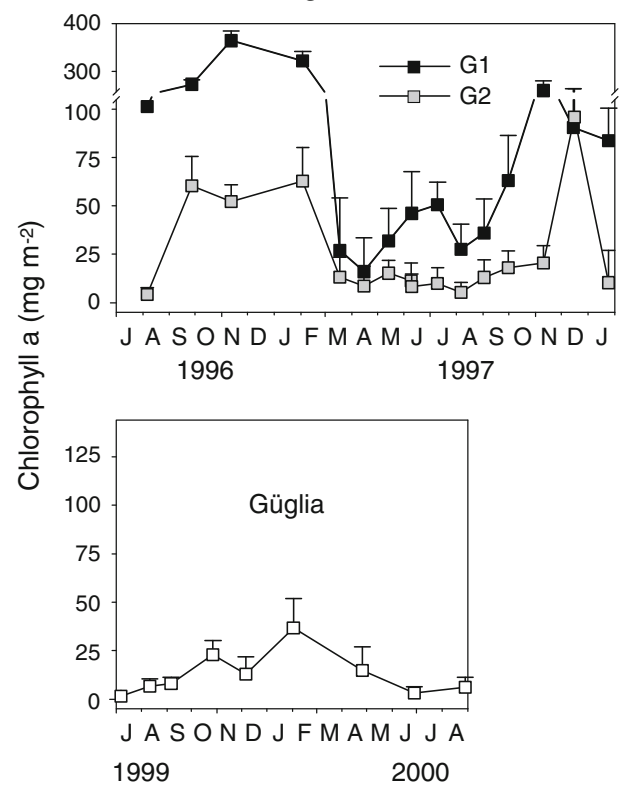

similar patterns). In the three glacial streams, Tschierva, Grindelwald and Lang, chlorophyll was low during summer (average values $0.6-4.9 \mathrm{mg}$ Chl. $a$ $\mathrm{m}^{-2}$ ), increased in September, peaked in October/ November (35-98 mg Chl. $a \mathrm{~m}^{-2}$ ), rapidly decreased through December/January (no data from Lang), and subsequently declined to summer low values. In two glacial streams, Morteratsch and Roseg Lake outlet, seasonal patterns were similar but relatively high biomass persisted until March/April (no snow cover at the Roseg and upper Morteratsch sites); average summer biomass equaled $8.1 \pm 6.7 \mathrm{mg}$ Chl. $a \mathrm{~m}^{-2}$ at the Morteratsch sites and $14.5 \pm 8.5 \mathrm{mg}$ Chl. $a \mathrm{~m}^{-2}$ at the Roseg site (stable bed sediments at the Roseg and upper Morteratsch site, Table 1). High biomass in autumn/winter and relatively low biomass in late spring and summer characterized the non-glacial streams; in G1 and G2, Chl. $a$ peaked in November at $329 \pm 0.39$ and $120 \pm 41 \mathrm{mg} \mathrm{m}^{-2}$, respectively. Average annual biomass in these two groundwaterfed streams exceeded that in the snowmelt-fed Güglia by two- to sevenfold. 

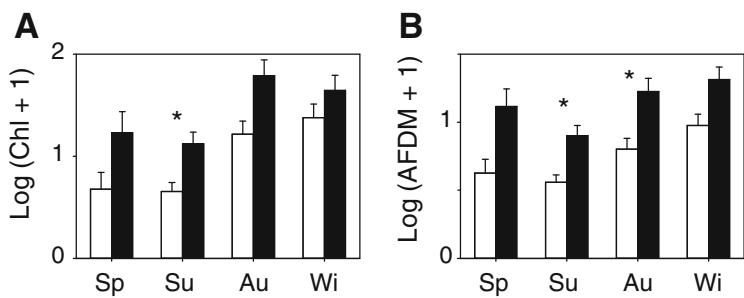

Fig. 6 Effect of season and stream type on chlorophyll $a$ (A) and ash-free dry mass (B). Bar plots with standard errors. Open bars = glacial streams. Filled bars $=$ non-glacial streams. Asterisks indicate significant differences between the two stream types (post-hoc Tukey's test). $S p$ spring, $S u$ summer, $A u$ Autumn, Wi winter

In glacial and non-glacial streams, seasonal differences in chlorophyll $a$ and ash-free dry mass were significant, and the overall seasonal patterns were similar in both stream types; i.e., low biomass during summer and high biomass in autumn and winter (Fig. 6). In non-glacial streams, biomass was significantly higher than in glacial streams (ANOVA, $P<$ $0.05)$.

Parallel to our study, Hieber et al. (2001) analyzed the structure of the algal communities of the five investigated glacial streams. Algal abundances showed strong seasonal variation, but seasonality in community composition (genera richness) was minor. Algal communities of the investigated glacial streams were dominated by Hydrurus foetidus during autumn and winter. The genera Achnanthes, Cymbella, and Fragilaria prevailed among diatoms, Lyngbya, Chamaesiphon, and Oscillatoria among cyanobacteria. Genera richness observed during the study varied between three (Lang, Tschierva) and 22 (Roseg).

\section{Discussion}

Periphyton biomass in the investigated Alpine glacial streams was low in summer and relatively high in autumn and, if sites were not covered by snow, also in winter. Apparently, suitable conditions in respect to flow, turbidity, and temperature did not coincide with enhanced vernal periphyton accrual. In nonglacial streams, vernal periphyton accrual was lacking and biomass continued to be relatively low during summer. This pattern does not support the hypothesis of two windows of opportunity for periphyton. Environmental conditions are apparently less suitable for periphyton in spring than in autumn. As seasonal biomass patterns were similar in non-glacial alpine streams to that of glacial streams, the low biomass in summer and high biomass in autumn/winter may be a general feature of periphyton dynamics in high alpine streams. This similarity in biomass patterns also suggests that besides turbidity, temperature, flow, and related factors such as shear stress and bed movement, other parameters should also be examined as potential constraints on periphyton.

The physico-chemical habitat template

The discharge regime of glacial streams is characterized by a distinct and predictable flow pulse (Uehlinger et al., 2003). In spring, rising air temperatures and solar radiation increase the release of melt water. Discharge in glacial streams peaks in July but remains high until mid-September. The glacial flow pulse usually coincides with substantial sediment transport that includes fine inorganic particles as well as bed load. Sediment stability plays a crucial role in periphyton accrual (Peterson, 1996) as moving bed sediments are a major constraint of periphyton accrual (Uehlinger et al., 1996). However, data on sediment transport or information on flow thresholds for sediment transport in glacial streams are usually lacking (e.g., Milner et al., 2001). Instead, channel stability indices based on hydraulic parameters, size and shape of grains, and vegetation have been used as a surrogate of substratum stability (Pfankuch, 1975; Hieber et al., 2002). In this study, evidence for the transport of coarse sediment includes lateral channel shifts (below the Tschierva and Lang glaciers) and burying of logging instruments in all glacial streams except Roseg.

Our calculations of critical discharge (initiation of bed load transport) suggest that bed load transport can occur at most glacial sites during summer high flow, but since discharge estimates for the study reaches are relatively rough, uncertainties about frequency and extent of periods with bed load transport are substantial. The forelands of receding glaciers are a rich source of sediment susceptible to fluvial transport during summer high flow. A proglacial lake such as Lake Roseg interrupts the downstream transport of coarse sediments from recently deglacierized forelands. As a consequence, corresponding outlet streams are considered to be relatively benign environments, at least in respect to the abrasive 
impact of moving sediments, unless coarse sediment is supplied from other sources (Hieber et al., 2002).

Solar radiation includes photosynthetically active radiation (PAR) as well as UV radiation with PAR as the ultimate source of energy for algae. High turbidity from high loads of suspended solids characterizes glacial streams during summer high flow. Concentrations of suspended solids positively correlate with discharge at a seasonal scale, but sediment concentrations can suddenly change without any noticeable change in discharge at the scale of hours (Gurnell, 1987). Depending on depth and turbidity, light availability to the stream bed can be strongly reduced. The relationship between turbidity and PAR attenuation determined in the Roseg catchment indicates that a turbidity of 250 NTU will attenuate about $95 \%$ of the incident light in a water column of $0.5 \mathrm{~m}$ depth (U. Uehlinger, unpublished data). In shallow streams (depth $<0.5 \mathrm{~m}$ ), an increase of 25 NTU is expected to decrease primary production by 13-50\% (Lloyd et al., 1987). A reduction in light intensity by $>90 \%$ largely reduces benthic primary production but may have a minor influence on periphyton standing crops (Hill et al., 2001). In the absence of scouring flow, biomass can still be relatively high although light attenuation is high. For example, in the turbid Roseg Lake outlet (estimated average light attenuation about $80 \%$ and lack of bed load transport), ash-free dry mass was several times higher than in the adjacent glacial stream below the Tschierva glacier (estimated average light attenuation about $90 \%$ ) during summer, i.e., $8.0 \pm 3.4$ vs. $1.0 \pm 04 \mathrm{~g} \mathrm{~m}^{-2}$.

Snow cover during winter is presumably more efficient in intercepting light than turbidity. Measurements in the Roseg catchment showed that a snowpack of $60 \mathrm{~cm}$ may reduce incident PAR light by 99\% (U. Uehlinger, unpublished data); snow depth in winter often exceed $1 \mathrm{~m}$ at elevations $>2,000 \mathrm{~m}$ a.s.1. We hypothesize that light exclusion by snow may be an important factor responsible for low biomass during winter. The extent to which glacial streams will be snow covered depends on local factors such as a lake (e.g., Lake Roseg outlet stream) or the upwelling of relatively warm groundwater (e.g., upper site at Morteratsch) (Schütz et al., 2001). Elucidating the availability of light as constraint of periphyton accrual in high alpine streams requires continuous monitoring of incident light, assessment of vertical light attenuation in the water column and snow pack, and quantitative monitoring of snow and ice cover in combination with periphyton colonization experiments using natural or artificial substrata.

In the Alps, global UV (direct and diffuse radiation) increases by about $11 \% \quad 1,000 \mathrm{~m}^{-1}$ (Schmucki \& Philipona, 2002). Moreover, high reflectivity of the ground and low aerosol concentrations further elevates UV-radiation levels in alpine environments. The intensity of UV radiation is subject to distinct seasonal variation: UV-A varies about 6 -fold and U-B around 20-fold (Blumthaler et al., 1992). In the Alps, at an elevation of $\sim 2,000 \mathrm{~m}$ a.s.l., the average intensity of incident UV radiation in spring (April, May) is about 2.5 times higher than in autumn (September, October) (Blumthaler et al., 1992). In spring, snow cover additionally increases the UV radiation load (Caldwell et al., 1980). Relatively high UV radiation and PAR intensities, shallow water, and low concentrations of dissolved organic matter may affect periphyton accrual in spring. Algae are more sensitive to UV stress at low temperature and relatively high PAR (Roos \& Vincent, 1998); i.e., under environmental conditions prevailing at high altitude. UV exclusion experiments have demonstrated that UV can suppress periphyton accrual (Bothwell, 1985, 1989; Bothwell et al., 1993; Vinebrooke \& Leavitt, 1996; Francoeur \& Lowe, 1998; Vinebrooke \& Leavitt, 1999).

Some authors have also found no significant effect of UV on periphyton (DeNicola \& Hoagland, 1996; Hill et al., 1997) and, over a long term, UV exposure even increased periphyton biomass presumably by reducing grazing impacts or bacterial competition for nutrients (Bothwell et al., 1993; Francoeur \& Lowe, 1998). Based on studies in alpine lakes, Vinebrooke and Leavitt (1996, 1999) hypothesized that in cold unproductive systems, the indirect impact of UV via the food web (e.g., reduced grazing) is low compared to the overall dominance of abiotic community regulation. A significant negative relationship between PAR and periphyton accrual was found in a stream-side channel experiment performed in the Alps at an elevation of 2,200 m a.s.l. (Wellnitz \& Ward, 2000). The investigation of Wellnitz \& Ward (2000) took place in September when light intensities were similar to those in spring. Field studies are needed for a decisive assessment of the potential UV/PAR-impact that comprises experimental manipulation of UV and PAR. 
Glacial streams are cold systems; temperatures are near $0^{\circ} \mathrm{C}$ even during summer at the snout of a glacier (Gíslason et al., 2001). Glacial streams reach maximum temperatures early in the year (May/early June). Rising solar radiation and air temperatures increase stream temperatures in spring, but with the release of cold meltwater, temperatures are persistently reduced compared to non-glacial streams at the same elevation (Uehlinger et al., 2003). In the Alps, water temperatures rapidly increase downstream (mean annual temperature by about $0.005^{\circ} \mathrm{C} \mathrm{m}^{-1}$ ), which limits the longitudinal extent of cold habitats (metakryal and hypokryal) and the phenomenon of the summer temperature depression (Uehlinger et al., 2003). Proglacial lakes increase outlet stream temperatures during summer compared to non-outlet glacial streams by several degrees (Hieber et al., 2002; Uehlinger et al., 2003). Low temperatures slow down algal growth rates, but periphyton biomass apparently reaches high values if discharge and turbidity are low and snow cover is lacking. For example, biomass increased to $30 \pm 14 \mathrm{~g} \mathrm{AFDM} \mathrm{m}^{-2}$ in March at the open upper Morteratsch site. Low temperature is apparently not a primary constraint for the formation of autotrophic biofilms in glacial streams.

The Alps receive relatively high amounts of nitrogen compounds by atmospheric deposition (Rhim, 1996). As a consequence, headwater streams in the Alps, including glacial streams, are characterized by nitrate concentrations typically $>200 \mu \mathrm{g} \mathrm{NO}_{3}-\mathrm{N}^{-1}$ (this study, Hieber et al., 2002; Robinson et al., 2002, this study, Tockner et al., 2002). These concentrations are high considering the fact that the transition from nitrogen limitation to nitrogen saturation is in the range of 50-60 $\mu \mathrm{g}^{-1}$ for inorganic nitrogen compounds (Grimm \& Fisher, 1986, Newbold, 1992). Experiments using nutrient diffusing substrata performed in alpine streams, including the proglacial reach below the Tschierva Glacier, indicated that periphyton accrual is not nitrogen limited (Robinson et al., 2002).

In contrast, phosphorus may become temporarily limiting in glacial and non-glacial streams. Concentrations of SRP varied from 0 (below detection limits) to a maximum of $6 \mu \mathrm{g} \mathrm{P} 1^{-1}$, which is in the range reported to limit algal growth (Bothwell, 1985; Newbold, 1992). Experiments with nutrient diffusing substrata performed in the Roseg River and other glacial streams indicate potential phosphorus limitation in spring but not in autumn; the results of summer experiments were inconsistent presumably due to the interference of abiotic factors such as current and glacial flour (Rinke et al., 2001; Robinson et al., 2002). Glacial flour can be a source or a sink of bio-available phosphorus (Bretschko, 1966; Hodson et al., 2004). Hodson et al. (2004) found that between 0.2 and $7 \%$ of the total $\mathrm{P}$ of glacial flour of different provenience may be potentially available for algae. However, we lack information about environmental conditions favoring desorption of $\mathrm{P}$ from glacial flour in the rivers investigated.

\section{Biotic processes}

Invertebrate grazing can negatively affect periphyton accrual in alpine streams (Wellnitz \& Ward, 2000). The few year-round investigations of glacial streams showed that benthic invertebrates can reach high densities at various times during the annual cycle (Burgherr \& Ward, 2000, Robinson et al., 2001; Schütz et al., 2001). Therefore, the hypothesis that grazing influences annual patterns of periphyton biomass in glacial streams, apart from abiotic factors, should be considered. Invertebrate densities in glacial streams are likely to be low during summer high flow and high between autumn and spring (Kowanacki, 1991; Gíslason et al., 2001, Robinson et al., 2001; Schütz et al., 2001; Burgherr et al., 2002), although deviations from this overall pattern can be substantial. For example, annual patterns of benthic grazers were quite different in some of the streams investigated in this study (Fig. 6 in Robinson et al., 2001). Overall, there exists no unequivocal coincidence of low invertebrate densities with high periphyton biomass and vice versa. A conclusive evaluation of a grazing impact in glacial streams would require field experiments similar to the stream-side channel study of Wellnitz \& Ward (2000) and was beyond the scope of this study.

Ecological windows of opportunity for periphyton?

The conceptual diagram in Fig. 7 is an attempt to summarize the potential relationships between regional climate and abiotic habitat conditions in Alpine glacial streams and the response of periphyton. Regional climate, topography, and geology are the ultimate factors controlling proximate factors such as 
REGIONAL CLIMATE

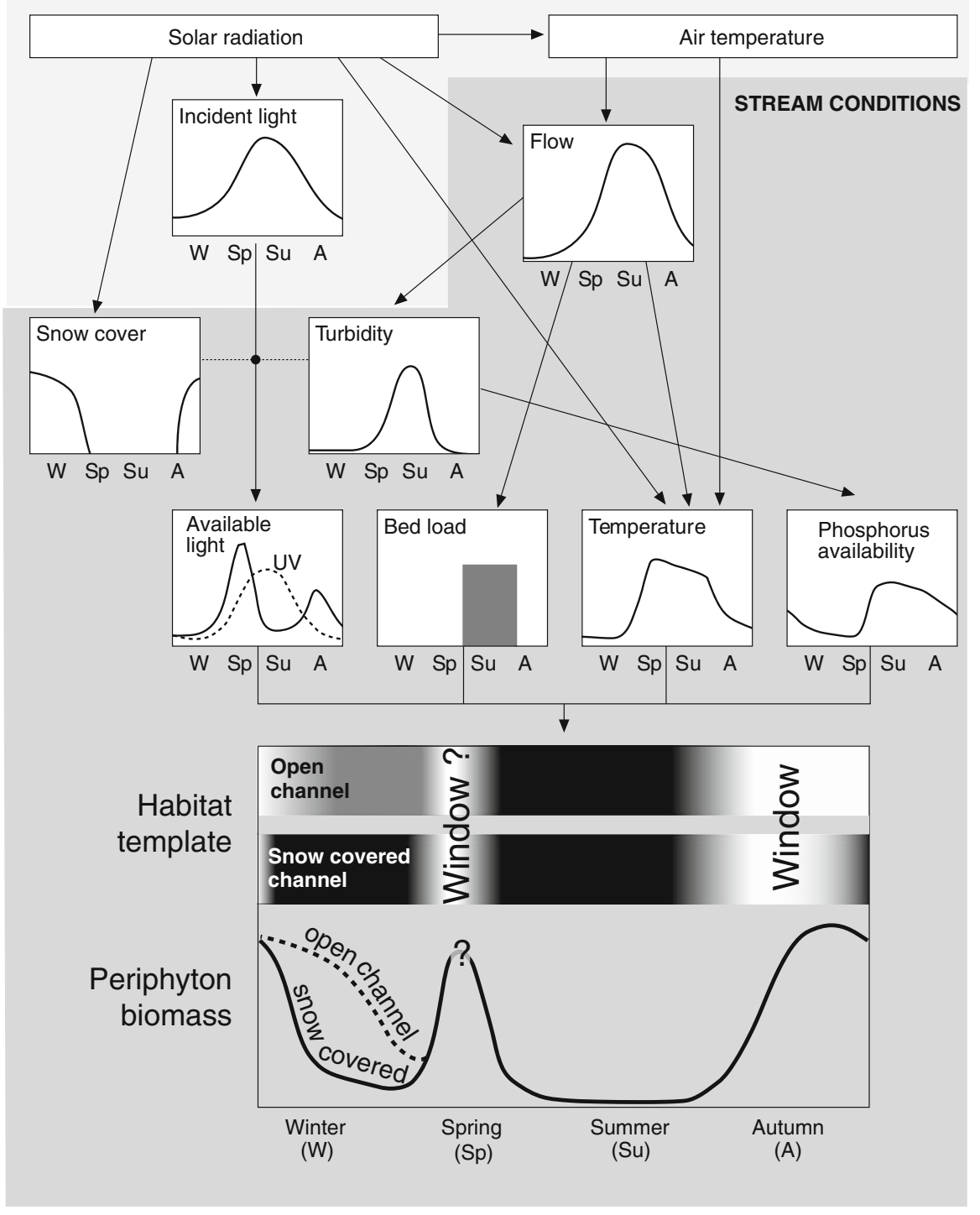

Fig. 7 Windows of opportunity for periphyton accrual in the physico-chemical habitat template of glacial streams in the Alps (conceptual diagram). Solar radiation and air temperature control discharge (melt of snow/ice, transient precipitation storage) and stream temperature. The cold meltwater halts the vernal temperature increase and keeps summer stream temperatures low. Glacial melt is paralleled by high turbidity (glacial flour) reducing PAR at the stream bottom. PAR availability also depends on the seasonally changing sun angle and the interception by snow if channels become snow covered; PAR

incident PAR and UV radiation, discharge (flow regime), shear stress, transport of fine (turbidity) and coarse sediments, and snow cover. Super-imposing annual patterns of the proximate factors result in exclusion by snow imposes a major constraint on algal growth. High levels of UV radiation may suppress periphyton in spring and summer. Transport of coarse sediments (bed load) occurs when flow is high, e.g., when warm summer weather enhances ice melt. The abrasive impact of moving sediment severely impedes periphyton accrual. Superimposing annual patterns of the proximate factors of influence delimits a relatively favorable period for periphyton growth in autumn and eventually in spring and, if the stream channel remains open, also in winter

periods during which environmental conditions are expected to favor or constrain periphyton accrual.

The period in autumn (mid-September to midNovember) is characterized by relatively low 
discharge (no transport of coarse sediments), low turbidity, moderate temperatures (considering constraints of the regional climate), and moderate solar radiation with respect to the impact, UV in particular. Low temperatures and low PAR intensities during winter (low solar angle, shading by aspect) apparently impose minor constraints on periphyton unless channels become covered by snow ( $>99 \%$ PAR exclusion). UV radiation, in combination with low temperature and relatively high PAR intensities, and/ or phosphorus limitation may suppress periphyton accrual in spring despite otherwise suitable flow conditions. However, Rott et al. (2006) reported spring periphyton peaks in a glacial stream of the Austrian Alps, in contrast to the findings of our study, suggesting the existence of a vernal opportunity window.

The conceptual model linking habitat conditions and periphyton patterns should be considered as a hypothesis for glacial streams in the Alps and presumably other high mountain ranges at temperate latitudes. We are aware that the database for generalizations about periphyton in these systems is still relatively small, and that further studies are needed to corroborate or refute assumptions, on which the model is based, such as, for example, the role of UV for periphyton accrual in spring or the lack of substantial biotic interactions.

\section{Climate change perspectives}

Predictions for catchments in the Swiss Alps suggest a decline in annual precipitation that is paralleled by increasing winter precipitation, decreasing summer precipitation, increasing evapotranspiration and major loss of glacierized areas (Horton et al., 2006; Zemp et al., 2006). In the catchment of the Roseg River, the glacier covered area is expected to decrease by $>90 \%$ and discharge by about $20 \%$ (median of regional climate model experiments, A2 and B2 scenarios defined by IPCC) to the end of this century (Horton et al., 2006). The shift from a glacier-driven to a snowfall/rainfall-driven flow regime will increase inter-annual flow variability (Horton et al., 2006) and, thus, reduce the predictability of the annual flow pulse. The flow pulse will also be shifted toward spring because of the earlier onset of snow melt and hydrographs may become more influenced by unpredictable rainstorms. Precipitation typically has a negative influence on glacial runoff, whereas in largely deglacierized catchments, precipitation rapidly turns into runoff (but see Röthlisberger \& Lang, 1987). In largely glacierized basins, the enhanced water yield due to increased air temperatures is expected to intensify the glacial flow pulse but only during an initial phase (Braun et al., 2000).

The loss of glaciers will result in a shift of water sources from snow/ice melt dominated to snow melt, rain and groundwater dominated during summer, and the flow regime will be similar to the nivo-pluvial regimes of lower Alpine regions (Braun et al., 2000). The reduced water yield in combination with minor subsurface water storage, shallow or lacking aquifers that typically characterize high Alpine basins, is expected to increase surface flow intermittency with declining glacierization. Today, flow intermittency of high elevation low-order Alpine streams can already be substantial. For example, Robinson and Matthaei (2007) documented that the wet channel network of a non-glacierized Swiss alpine catchment contracted by more than $60 \%$ in late autumn, and Tonolla (2005) showed that about $90 \%$ of the surface channels fell dry by autumn in the Roseg catchment. The receding glaciers expose large amounts of unconsolidated sediments susceptible to fluvial transport during the meltwater peak and rainfall induced spates presumably increase the devastating impact of such events for sessile organisms. The shift in water source also will cause water temperatures to become warmer as well. All these changes will likely influence the distributions and abundances of macroinvertebrates with some lower elevation species already colonizing high elevation streams in the Alps (D. Finn, unpublished data) as well as benthic primary producers. The amount and kinds of riparian vegetation are also expected to change with potential effects on carbon and nutrient relationships in adjacent streams.

Based on these expectations, we predict in the long term that the windows of opportunity for periphyton growth to shift in running waters of the Alps with decreasing glacial influence and raising temperatures. In spring, periphyton development should be more limited by higher flows that mobilize sediments, reduce transparency, and thus presumably confound the impact of high solar UV. The high flows should also limit the effects of grazing by invertebrates. On the other hand, if the channel snow cover disappears earlier than today, the UV impact during the spring 
low flow period will be smaller and periphyton may accumulate before increasing discharge impose constraints. Already, early summer flows will be influenced by periodic extreme events that may scour periphyton and reduce biomass, although recovery should be relatively rapid. Water clarity should be improved with the reduction in glacial meltwater and inputs of glacial flour. Lower flows should occur earlier in late summer when light and temperature conditions become more optimal for periphyton growth, but this effect may be offset by high UV radiation. The autumnal window of opportunity may shift earlier in alpine catchments and extend into late autumn in channels that retain surface flows. Flowing water channels also may stay open longer and not become snow covered until late winter, further extending the window for periphyton growth. The counter effects by grazing invertebrates may limit somewhat periphyton development. In perennial systems with no or minor glacial influence, seasonal biomass pattern may still be similar to those observed today in non-glacial streams apart from an eventually early vernal and an extended autumnal/winter peak. However, major changes in seasonal patterns are expected when streams fall dry, e.g., if surface flow already ends in late summer and only resumes in spring. When glaciers disappear, this becomes a realistic scenario for rivers, the surface flow of which strongly depends on the recharge of the valley aquifer by the glacial flow pulse (Malard, 2003).

Acknowledgements We thank R. Illi and B. Ribi for analyses of water chemistry and chlorophyll $a$, and the Swiss Federal Office for Water and Geology for discharge data of several streams. We appreciate the helpful comments of two anonymous reviewers.

\section{References}

Blumthaler, M., W. Ambach \& W. Rehwald, 1992. Solar UV$A$ and UV-B radiation fluxes at two Alpine stations at different altitudes. Theoretical and Applied Climatology 46: 39-44.

Bothwell, M. L., 1985. Phosphorus limitation of lotic periphyton growth rates: an intersite comparison using continuous-flow troughs (Thompson River system, British Columbia). Limnology and Oceanography 30: 527-542.

Bothwell, M. L., 1989. Phosphorus-limited growth dynamics of lotic periphytic diatom communities: areal biomass and cellular growth rate responses. Canadian Journal of Fisheries and Aquatic Sciences 46: 1293-1301.
Bothwell, M. L., D. Sherbot, A. C. Roberge \& R. J. Daley, 1993. Influence of natural ultraviolet radiation on lotic periphytic diatom community growth, biomass accrual, and species composition: short-term versus long-term effects. Journal of Phycology 29: 24-35.

Braun, L. N., M. Weber \& M. Schulz, 2000. Consequences of climate change for runoff from Alpine regions. Annals of glaciology 31: 19-25.

Bretschko, G., 1966. Untersuchung zur Phosphatführung zentralalpiner Gletscherabflüsse. Archiv Fur Hydrobiologie 62: 327-338.

Brown, L. E., A. M. Milner \& D. M. Hannah, 2006. Stability and persistence of alpine stream macroinvertebrate communities and the role of physical habitat variables. Hydrobiologia 560: 159-173.

Burgherr, P., 2000. Spatio-temporal community patterns of lotic zoobenthos across habitat gradients in an alpine glacial stream ecosystem. PhD thesis. Swiss Federal Institute of Technology, Zurich, Zürich.

Burgherr, P. \& J. V. Ward, 2000. Zoobenthos of kryal and lake outlet biotopes in a glacial floodplain. Verhandlungen der Internationalen Vereinigung für Theoretische und Angewandte Limnologie 27: 1587-1590.

Burgherr, P., J. V. Ward \& C. T. Robinson, 2002. Seasonal variation in zoobenthos across habitat gradients in an alpine glacial floodplain (Val Roseg, Swiss Alps). Journal of the North American Benthological Society 21: 561-4575.

Caldwell, M. M., R. Robberecht \& W. D. Billings, 1980. A steep latitudinal gradient of solar ultraviolet-B radiation in the Arctic-Alpine life zone. Ecology 61: 600-611.

Castella, E., H. Adalsteinsson, J. E. Brittain, G. M. Gíslason, A. Lehmann, V. Lencioni, B. Lods-Crozet, B. Maiolini, A. M. Milner, J. S. Ólafsson, S. J. Saltveit \& D. L. Snook, 2001. Macrobenthic invertebrate richness and composition along a latitudinal gradient of European glacier-fed streams. Freshwater Biology 46: 1811-1831.

Davis, J. C., G. W. Minshall, C. T. Robinson \& P. Landres, 2001. Monitoring wilderness stream ecosystems. General Technical Report RMRS-GTR-70. United States Department of Agriculture, Forest service. Rocky Mountain Research Station, Ogden.

DeNicola, D. M. \& K. D. Hoagland, 1996. Effects of solar spectral irradiance (visible to UV) on a prairie stream epilithic community. Journal of the North American Benthological Society 15: 155-169.

Francoeur, S. N. \& R. L. Lowe, 1998. Effects of ambient ultraviolet radiation on littoral periphyton: biomass accrual and taxon-specific responses. Journal of Freshwater Ecology 13: 29-37.

Füreder, L., 1999. High alpine streams: cold habitats for insect larvae. In Margesin, R. \& F. Schinner (eds), Cold-Adapted Organisms. Ecology, Physiology, Enzymology and Molecular Biology. Springer, Berlin: 181-195.

Gessler, J., 1965. Der Geschiebetriebbeginn bei Mischungen untersucht an natürlichen Abpflästerungserscheinungen in Kanälen. Mitteilungen der Versuchsanstalt für Wasserund Erdbau der ETH Zürich 69: 1-67.

Gíslason, G. M., H. Adalsteinsson, I. Hanson \& K. Svavarsdóttir, 2001. Longitudinal changes in macroinvertebrate assemblages along a glacial river system in central Iceland. Freshwater Biology 46: 1737-1751. 
Gordon, N. D., T. A. McMahon \& B. L. Finlayson, 1992. Stream Hydrology. An Introduction for Ecologists. Wiley, Chichester.

Grimm, N. B. \& S. G. Fisher, 1986. Nitrogen limitation in a Sonoran Desert (Arizona, USA) stream. Journal of the North American Benthological Society 5: 2-15.

Günter, A., 1971. Die kritische mittlere Sohlenschubspannung bei Geschiebemischungen unter Berücksichtigung der Deckschichtbildung und der turbulenzbedingten Sohlenschubspannungsschwankunen. Mitteilungen VAW 3. Laboratory of Hydraulics, Hydrology and Glaciology, Swiss Federal Institute of Technology, Zürich.

Gurnell, A. M., 1987. Suspended sediment. In Gurnell, A. M. \& M. J. Clark (eds), Glacio-Fluvial Sediment Transfer. Wiley, Chichester: 305-354.

Hawes, I., C. Howard-Williams \& W. F. Vincent, 1992. Desiccation and recovery of Antarctic Cyanobacterial Mats. Polar Biology 12: 587-594.

Hieber, M., C. T. Robinson, S. R. Rushforth \& U. Uehlinger, 2001. Algal communities associated with different alpine stream types. Arctic, Antarctic, and Alpine Research 33: 447-456.

Hieber, M., C. T. Robinson, U. Uehlinger \& J. V. Ward, 2002. Are alpine lake outlets less harsh than other alpine streams? Archiv Fur Hydrobiologie 154: 199-223.

Hieber, M., C. T. Robinson, U. Uehlinger \& J. V. Ward, 2005. A comparison of benthic macroinvertebrate assemblages among different types of alpine streams. Freshwater Biology 50: 2087-2100.

Hill, W. R., S. M. Dimick, A. E. McNamara \& C. A. Branson, 1997. No effect of ambient UV radiation detected in periphyton and grazers. Limnology and Oceanography 42 : 769-774.

Hill, W. R., P. J. Mulholland \& E. R. Marzolf, 2001. Stream ecosystem response to forest leaf emergence in spring. Ecology 82: 2306-2319.

Hodson, A., P. Mumford \& D. Lister, 2004. Suspended sediment and phosphorus in proglacial rivers: bioavailability and potential impacts upon the $\mathrm{P}$ status of ice-marginal receiving waters. Hydrological Processes 18: 2409-2422.

Horton, P., B. Schaefli, A. Mezghani, B. Hingray \& A. Musy, 2006. Assessment of climate-change impacts on alpine discharge regimes with climate model uncertainty. Hydrological Processes 20: 2091-2109.

Howard-Williams, C. \& W. F. Vincent, 1989. Microbial communities in southern Victoria Land streams (Antarctica). I. Photosynthesis. Hydrobiologia 172: 27-38.

Howard-Williams, C., C. L. Vincent, P. A. Broady \& W. F. Vincent, 1986. Antarctic stream ecosystems: variability in environmental properties and algal community structure. Internationale Revue der Gesamten Hydrobiologie 71: 511-544.

Kowanacki, A., 1991. Zonal distribution and classification of the invertebrate community in high mountain streams in South Tyrol (Italy). Verhandlungen der Internationalen Vereinigung für Theoretische und Angewandte Limnologie 24: 2010-2014.

Lavandier, P. \& H. Décamps, 1984. Estaragne. In Whitton, B. A. (ed.), Ecology of European Rivers. Blackwell, Oxford: 237-263.
Lloyd, D. S., J. P. Koenings \& J. D. LaPerriere, 1987. Effects of turbidity in fresh waters of Alaska. North American Journal of Fisheries Management 7: 18-33.

Malard, F., 2003. Groundwater-surface water interactions. In Ward, J. V. \& U. Uehlinger (eds), Ecology of a Glacial Flood Plain. Kluwer Academic Publishers, Dordrecht: 3756.

Malard, F., U. Uehlinger, R. Zah \& K. Tockner, 2006. Floodpulse and riverscape dynamics in a braided glacial river. Ecology 87: 704-716.

McKnight, D. M. \& C. M. Tate, 1997. Canada stream: a glacial meltwater stream in Taylor Valley, South Victoria Land, Antarctica. Journal of the North American Benthological Society $16: 14-17$.

Meyns, S., R. Illi \& B. Ribi, 1994. Comparison of chlorophylla analysis by HPLC and spectrophotometry: where do the differences come from? Archiv Fur Hydrobiologie 132: 129-139.

Milner, A. M. \& G. E. Petts, 1994. Glacial rivers: physical habitat and ecology. Freshwater Biology 32: 295-307.

Milner, A. M., J. E. Brittain, E. Castella \& G. E. Petts, 2001. Trends of macroinvertebrate community structure in glacier-fed rivers in relation to environmental conditions: a synthesis. Freshwater Biology 46: 1833-1847.

Milner, A. M., L. E. Brown \& D. M. Hannah, 2009. Hydroecological response of river systems to shrinking glaciers. Hydrological Processes 23: 62-77.

Newbold, D. J., 1992. Cycles and spirals of nutrients. In Calow, P. \& G. E. Petts (eds), The Rivers Handbook. Hydrological and Ecological Principles. Blackwell, London: 379-408.

Paul, F., 2003. The new Swiss glacier inventory 2000. PhD. University of Zurich, Zurich.

Peterson, C. G., 1996. Response of benthic algal communities to natural physical disturbance. In Stevenson, R. J., M. L. Bothwell \& R. L. Lowe (eds), Algal Ecology. Freshwater Benthic Ecosystems. Academic Press, San Diego: 375402.

Pfankuch, D. J., 1975. Stream Reach Inventory and Channel Stability Evaluation. U.S.D.A. Forest Service, Missoula, Montana.

Rhim, R., 1996. Critical Loads of Nitrogen and their Exceedances. Environmental Series 275, Swiss Agency for the Environment, Forests and Landscape. Berne, Switzerland.

Rinke, K., C. T. Robinson \& U. Uehlinger, 2001. A note on abiotic factors that constrain periphyton growth in Alpine glacier streams. International Review of Hydrobiology 86 : 361-366.

Robinson, C. T. \& S. Matthaei, 2007. Hydrological heterogeneity of an Alpine streamlake network in Switzerland. Hydrological Processes 21: 3146-3154.

Robinson, C. T., U. Uehlinger \& M. Hieber, 2001. Spatiotemporal variation in macroinvertebrate assemblages of glacial streams in the Swiss Alps. Freshwater Biology 46: 1663-1672.

Robinson, C. T., U. Uehlinger, F. Guidon, P. Schenkel \& R. Skvarc, 2002. Limitation and retention of nutrients in alpine streams of Switzerland. Verhandlungen der Internationalen Vereinigung für Theoretische und Angewandte Limnologie 28: 263-272. 
Roos, J. C. \& W. F. Vincent, 1998. Temperature dependence of UV radiation effects on Antarctic cyanobacteria. Journal of Phycology 43: 118-125.

Röthlisberger, H. \& H. Lang, 1987. Glacial hydrology. In Gurnell, A. M. \& M. J. Clark (eds), Glacio-Fluvial Sediment Transfer. Wiley, Chichester: 207-284.

Rott, E., M. Cantonati, L. Füreder \& P. Pfister, 2006. Benthic algae in high altitude streams of the Alps-a neglected component of the aquatic biota. Hydrobiologia 562: 195216.

Schmucki, D. \& R. Philipona, 2002. Ultraviolet radiation in the Alps: the altitude effect. Optical Engineering 41: 3903095.

Schütz, C., M. Wallinger, R. Burger \& L. Füreder, 2001. Effects of snow cover on the benthic fauna in a glacier-fed stream. Freshwater Biology 46: 1691-1704.

Tockner, K., F. Malard, P. Burgherr, C. T. Robinson, U. Uehlinger, R. Zah \& J. V. Ward, 1997. Physico-chemical characterization of channel types in a glacial floodplain ecosystem (Val Roseg, Switzerland). Archiv Fur Hydrobiologie 140: 433-463.

Tockner, K., F. Malard \& J. V. Ward, 2000. An extension of the flood pulse concept. Hydrological Processes 14: 28612883.

Tockner, K., F. Malard, U. Uehlinger \& J. V. Ward, 2002. Nutrients and organic matter in a glacial river floodplain system (Val Roseg, Switzerland). Limnology and Oceanography 47: 521-535.

Tonolla, D., 2005. Characterization of the temporary hydrosystem of a high alpine catchment (Val Roseg, Switzerland) by GIS mapping and assessment of morphological features. Diploma Thesis, Swiss Federal Institute of Technology, Zurich.

Uehlinger, U., 1991. Spatial and temporal variability of the periphyton biomass in a prealpine river (Necker, Switzerland). Archiv Fur Hydrobiologie 123: 219-237.

Uehlinger, U. \& R. Zah, 2003. Organic matter dynamics. In Ward, J. V. \& U. Uehlinger (eds), Ecology of a Glacial Floodplain. Kluwer Academic Publishers, The Hague: 199-215.

Uehlinger, U., H. Bührer \& P. Reichert, 1996. Periphyton dynamics in a floodprone prealpine river: evaluation of significant processes by modelling. Freshwater Biology 36: 249-263.
Uehlinger, U., R. Zah \& J. V. Ward, 1998. The Val Roseg Project: temporal and spatial patterns of benthic algae in an Alpine stream ecosystem influenced by glacier runoff. In Kovar, K., U. Tappeiner, N. E. Peters \& R. G. Craig (eds), Hydrology, Water Resources and Ecology in Headwaters. IAHS Press, Wallingford, U.K: 419-424.

Uehlinger, U., K. Tockner \& F. Malard, 2002. Ecological windows in glacial stream ecosystems. EAWAG News 54e: 16-17, 20-21.

Uehlinger, U., F. Malard \& J. V. Ward, 2003. Thermal patterns in the surface waters of a glacial river corridor (Val Roseg, Switzerland). Freshwater Biology 48: 284-300.

Vincent, W. F. \& C. Howard-Williams, 1989. Microbial communities in southern Victoria Land streams (Antarctica) II. The effects of low temperature. Hydrobiologia 172: 39-49.

Vinebrooke, R. D. \& P. R. Leavitt, 1996. Effects of ultraviolet radiation on periphyton in an alpine lake. Limnology and Oceanography 41: 1035-1040.

Vinebrooke, R. D. \& P. R. Leavitt, 1999. Differential responses of littoral communities to ultraviolet radiation in an alpine lake. Ecology 80: 223-237.

Ward, J. V., 1994. Ecology of alpine streams. Freshwater Biology 32: 277-294.

Ward, J. V. \& U. Uehlinger (eds), 2003. Ecology of a Glacial Flood Plain. Kluwer Academic Publishers, Dordrecht.

Watson, R. T., M. C. Zinyowera \& R. H. Moss, 1997. The Regional Impacts of Climate Change: An Assessment of Vulnerability. Cambridge University Press, Cambridge.

Wellnitz, T. A. \& J. V. Ward, 2000. Herbivory and irradiance shape periphytic architecture in a Swiss alpine stream. Limnology and Oceanography 45: 64-75.

Zah, R. \& U. Uehlinger, 2001. Particulate organic matter inputs to a glacial stream ecosystem in the Swiss Alps. Freshwater Biology 46: 1597-1608.

Zar, J. H., 1996. Biostatistical Analysis. Prentice Hall, Upper Saddle River, N.J.

Zbinden, M., M. Hieber, C. T. Robinson \& U. Uehlinger, 2008. Short-term colonization patterns of macroinvertebrates in alpine streams. Fundamental and Applied Limnology 171: $75-86$.

Zemp, M., W. Haeberli, M. Hoelzle \& F. Paul, 2006. Alpine glaciers to disappear within decades. Geophysical Research Letters 33: L13501-L13504. 